\title{
The Micro and Macro Analysis of English and Arabic Religious Texts
}

\author{
Baida Faisal Al-Araji \\ Department of English, College of Arts, University of Baghdad, Iraq \\ E-mail: baidaa_alarajy@yahoo.com \\ Sarab Khalil Al-Azzawi (Corresponding author) \\ Department of English, College of Arts, University of Baghdad, Iraq \\ E-mail: Sarab_khalil@yahoo.com
}

Doi:10.7575/aiac.alls.v.7n.6p.271

Received: $12 / 10 / 2016$

URL: http://dx.doi.org/10.7575/aiac.alls.v.7n.6p.271

Accepted: 30/11/2016

\begin{abstract}
Religious discourse has been treated differently in various types of studies. In the present study, the English Biblical and Arabic Prophetic Hadiths will be tackled on two bases namely the micro and macro levels. In other words, the data will be analyzed at both micro and macro levels to maintain the organizational status of the religious texts. The macro level is concerned with the topic, the main theme and the gist of each text, whereas the micro level investigates the lexical, syntactic and rhetorical aspects of the selected texts. The data consists of 12 religious texts 6 of which is concerned with the English biblical texts and the other 6 is concerned with the Arabic Prophetic Hadiths. The 12 texts are selected on the basis of the similarity in their themes. The study tries to answer the following:

1. How is the macro structure represented by the micro aspects of language, namely the lexical, syntactic and rhetorical aspects?

2. Are there any similarities and/or differences between the two types of texts regarding the micro levels of both languages?

3. How are lexical, syntactic and rhetorical devices realized in the selected texts in both languages?
\end{abstract}

Keywords: English religious texts, Arabic religious texts, discourse studies

\section{Introduction}

This study starts from the question about how the macro structure of any type of a text is achieved through the micro features of that text. Generally speaking, the micro type of analysis describes the immediate lexical, syntactic and rhetorical interrelations holding within any type of a text. In other words, the micro features of a text relate the linguistic components of a text (the local level) to the overall logical form of it (the global level) (van Dijk, 1972:17).

The macro level, on the other hand, is the higher level representing the topic, theme, or gist of a text, i.e. it is concerned with what the text is about. The macro form is arrived at through a set of micro features applied to the sequence of propositions locally expressed by the text. Accordingly, any proposition entailed by a subset of a sequence of micro features may function as a macro form for that sequence (van Dijk, 1985:117). According to van Dijk (1981:196), macro structures are semantic constructs making explicit the topic of discourse, i.e. they indicate the subject matter of discourse. Nevertheless, there is a general consensus regarding the components of the macro level (ibid). For more details of such components, see van Dijk (1977:137) and Hamburger (1981: 129).

\section{The Models of Micro \& Macro Structures}

The micro approach deals with the linguistic elements of a text such as tenses, types of sentences, pronoun types (relative, reflexive, etc), prepositions, verbs, etc. these micro units constitutes the local level features of a text such as sentences, clauses and phrases. They focus on vocabulary and grammar including cohesive relations and grammatical regularities, (Bellert,1970:336, 1971:232-8 and van Dijk and Kintsch, 1983:52).

The interaction between the macro and micro structures, as Hamburger (1981:116) states, constitutes the coherence of a text, i.e. the elements of micro structure can be directly filled into the relevant constituents of the macro structure of that text. He (ibid) adds that both micro and macro structures have to be broken down into logical units. Each unit of macro structure is fragmented over a number of micro structure elements which are not arbitrary elements, but represented semantically in the macro structure, (ibid: 130).

According to van Dijk's framework (1980), the notion of 'Macro Structure' stands for the global meaning of a text; it refers to the higher- level semantic or conceptual structures which organize the local constituents (the micro structure) of a text (ibid: 41). Accordingly, the macro structure of a text indicates the theme and the topic of that text. 


\section{The Micro and Macro Analysis of the Data Selected}

The analysis adopted in this study makes use of the approaches mentioned previously in section two, to say it in another way, regarding the micro analysis; the focus will be on the lexical or word level. In this level; verbs, as they are the theme holder, are analyzed according to whether they are transitive/ intransitive and action/state. Since the study deals with the religious discourse, it tries to examine if there is a specific use of religious words/ expressions. The second level is the syntactic or sentence level. It investigates the types of sentences used in this type of register (simple, compound or complex), the modes of sentences (statements, imperative, and interrogative), the passive constructions, and tenses.

The third level is the rhetorical. In this level rhetorical devices like metaphor, simile, personification, parallelism, etc are analyzed. The reason behind choosing rhetorical devices to be within the micro analysis adopted in this study is that they have recognizable communicative and pragmatic implications. Moreover, they play a very important role in facilitating communication and providing a setting for the conveyance of the intended message and goals of a text.

In the macro analysis, semantically and pragmatically speaking, the focus will be on the theme of the text. The study will examine how many themes each text tackles and also whether such themes are explicitly or implicitly expressed.

\section{The Analysis of the English Data}

Text 1:

In this same way, husbands ought to love their wives as their bodies. He who loves his wife loves himself ( Ephesians 5:28)

The gist of the first biblical text is that women should be highly respected and appreciated. The text consists of two sentences of relatively similar length. The verbs used are of state type (love). In both sentences transitive verbs are used to pack a lot of information. All the verbs are in the present tense. No specific use of religious words is found. Both sentences are complex. Their mode is statement. As for the rhetorical devices, simile is used in the elliptical structure "as their bodies", the second device is Amplification for the word "love".

\section{Text 2:}

A gentle answer turns away wrath, but a harsh word stirs up anger (Proverbs 15:1)

The theme of this text is how to speak gently. Two action verbs are used which are also transitive "turn away and stir up". The verbs are in the present tense. The text consists of one compound sentence of a statement mode. No religious words are used. As for the rhetorical devices, antithesis is used to express the main theme of this text.

Text 3:

Children, obey your parents in the Lord, for this is right. Honor your father and mother which is the first commandment with a promise. (Ephesians 6: 1,2)

The theme of this text is to love, obey, assist and respect your parents in everything to gain blessings from God. Two action verbs are used "obey" and "honor" which are transitive too. The text consists of two sentences. Both of which are complex and in an imperative mode. Only one religious word is used "Lord". As for the rhetorical devices, there is a specific use of parallel structures in "obey your" and "honor your" to make the text of a smooth flow and be persuasive. It also gives balance to the sentences.

Text 4:

Do not testify against your neighbor without cause or use your lips to deceive (Proverbs 24:28)

The gist of this text is about neighbors and how to treat them well. Two action verbs are found 'testify' and 'use'. The verbs are in the present tense. The first is intransitive and the second is transitive. This text is of one compound sentence in an imperative mode. No religious words are used. No rhetorical devices are found.

Text 5:

Humble yourselves, therefore, under God's mighty hand, that He may lift you up in due time (1Peter 5:6)

This text provides a moral lesson and advice one to be modest and not arrogant because whoever is humble God will raise his/her status at the appropriate time. There are two verbs in this text. One is state 'humble' and the other is action 'lift' and both are transitive. The verbs are in the present tense. The text consists of one complex sentence of imperative mode. Religious words are noticed here like 'God', 'Mighty' and 'due time'. Also rhetorical devices are used here like Epithet 'mighty hand' for a descriptive purpose.

\section{Text 6:}

\section{Keep your tongue from evil and your lips from telling lies (Psalms 34:13)}

The theme of this text is to give a moral lesson in which one should keep ones tongue and lips from telling lies. Two action verbs are used "keep" and "tell". Both are transitive and in the present tense. The text consists of one compound sentence. The sentence is in an imperative mode. There is a religious word in the text which is 'evil'. As for the rhetorical devices, there is a variety of parallel structures and repetition in "keep your tongue from evil" and "keep your lips from telling lies" to give the sentence balance, rhythm and flow. 
Table 1. The Distribution of Micro Structures in the English Data

\begin{tabular}{|c|c|c|c|c|c|c|c|c|c|c|c|c|c|c|}
\hline \multirow[b]{3}{*}{ 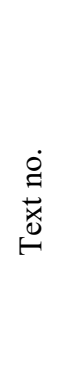 } & \multicolumn{5}{|c|}{ The word level } & \multicolumn{8}{|c|}{ The sentence level } & \multirow{3}{*}{ 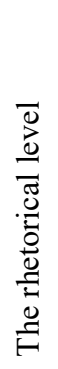 } \\
\hline & \multirow[b]{2}{*}{ 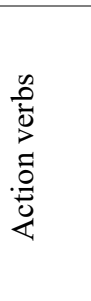 } & \multirow[b]{2}{*}{ 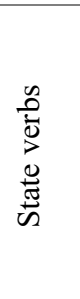 } & \multirow[b]{2}{*}{ 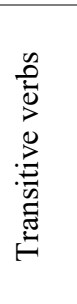 } & \multirow{2}{*}{ 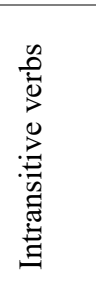 } & \multirow[b]{2}{*}{ 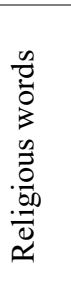 } & \multicolumn{3}{|c|}{ Sentence Type } & \multicolumn{3}{|c|}{ Sentence Mode } & \multicolumn{2}{|l|}{ Tenses } & \\
\hline & & & & & & 苛 & $\begin{array}{l}\bar{\Xi} \\
\Xi \\
0 \\
\stackrel{\Xi}{0} \\
0\end{array}$ & 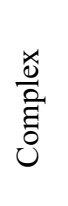 & 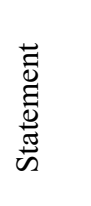 & 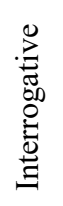 & 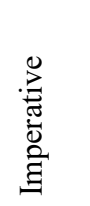 & 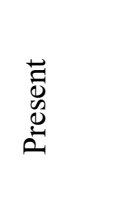 & $\begin{array}{l}\text { 苛 } \\
\text { है }\end{array}$ & \\
\hline 1 & & 3 & 3 & & & & & 2 & 2 & & & 3 & & 2 \\
\hline 2 & 2 & & 2 & & & & 1 & & 1 & & & 2 & & \\
\hline 3 & 2 & & 2 & & 1 & & & 2 & & & 2 & & & 1 \\
\hline 4 & 2 & & 1 & 1 & & & 1 & & & & 1 & 2 & & \\
\hline 5 & 1 & 1 & 2 & & 3 & & & 1 & & & 1 & 2 & & 1 \\
\hline 6 & 2 & & 2 & & 1 & & 1 & & & & 1 & 2 & & 1 \\
\hline Total & 9 & 4 & 12 & 1 & 5 & & 3 & 5 & 3 & & 5 & 11 & & 5 \\
\hline$\%$ & 14.2 & 6.3 & 19.0 & 1.5 & 7.9 & & 4.7 & 7.9 & 7.7 & & 7.9 & 17.4 & & 7.9 \\
\hline
\end{tabular}

Table (1) shows a significant use of action verbs (14.2\%) and transitive verbs (19\%) in comparison with the other types of verbs, namely state and intransitive verbs. This proves that such types of texts are primarily concerned with the explication of actions and deeds in the form of end - focus type of information structure. Regarding the sentence level, compound type of sentences has the highest rate of frequency (9.7\%) among the other types of sentences. This indicates that there is a tendency towards the use of a less condensed style. As far as the sentence mode is concerned, statements are significantly used $(9.7 \%)$ in comparison with the other modes. The six selected data are presented in the present tense. No use of passive constructions is noted. As for the rhetorical level, there is a variety in the use of rhetorical devices.

\section{The Analysis of the Arabic Data}

\section{Text 1:}

$$
\text { واستوصو ا بالنساء خيرا (البخاري -5186 ) }
$$

The theme of this text is "the women treatment" specifically men, should act kindly towards women. At the word level, there is only one verb which is intransitive and action. As a religious word استوصو ا belongs to this genre.

At the sentence level, it is a text of one simple sentence in the imperative mode. No rhetorical devices are found.

Text 2:

$$
\text { رحم الله عبدا قال خير ا فغنم او سكت عن سوء فسلم (بحار الانوار ج } 71 \text { / ص 293/ ح 64) ع }
$$

The main theme of this text is that one should select his words effectively, if he says something, he should not hurt others, i.e. a good word is charity. Regarding the micro analysis, there is a variety of transitive and intransitive verbs. They express both meanings: state and action. There is a specific use of religious words and expressions for example ، رحم ،سلم، غنم ، سوء ، خير the text is of one complex sentence whose mode is statement. The sentence consists of five verbal clauses all in the simple past tense. Parallelism, repetition and antithesis are employed as rhetorical devices.

Text 3:

$$
\text { كن بار او اقتصر على الجنة، وان كنت عاقا فاقتصر على النار ( الو افي / ج 3/ ص 155) }
$$

As for the macro analysis, the gist of the above text is that honor and take care of your parents. If you want the paradise, otherwise the hell will be yours.

As the micro analysis is concerned, the same verb is used twice اقتصر which is intransitive and action. The base from ( كينونة is used in two forms: 'كن ' كنت ' as a state verb in an imperative mode and a state verb in a statement mode. Religious words are significantly used in this text like: الجنة، النار، عاق، بار the text is of one complex sentence containing four verbal clauses; all of them except the third clause which is statement whose tense is simple past are in the imperative mode. Parallel structure and repetition are significantly used to express the same idea. 


\section{Text 4:}

$$
\text { حسن الجوار يعمر الديار او ينسىء في الاعمار (الكافي - ج } 2 \text { ص } 667 \text { ) }
$$

"Neighbourliness causes the lands to thrive and increases life spans".

The gist of the text is that good neighborly is one of the great morals in Islam. As for the linguistic analysis one religious word is noticed that is 'ينسى؟'. Two action verbs are found; one of them is transitive and the other is intransitive. It is a compound sentence containing two verbal clauses whose tense is simple present. The two clauses are considered to be statements. In order to achieve affective implications parallelism and ellipsis are used noticeably.

\section{Text 5:}

$$
\text { من تو اضع الله رفعه الله (البيهيقي 8140) }
$$

As for the macro analysis, the main theme of this text is "modesty". Moreover the text tells that he who submits himself to God will be exalted by God. At the word level, all the words used in this text belong to the religious genre e.g. لف

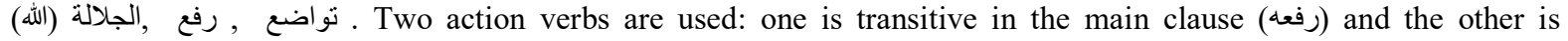
intransitive in the subordinate one (تواضع). At the sentence level, the text is of one complex sentence whose mode is statement. The sentence, as a whole, is expressed in the simple past tense. At the rhetorical level, parallelism and repetition are noticeably employed to express the same meaning or idea.

Text 6:

$$
\text { من غشنا فليس منا (مسلم 101) }
$$

The theme of this text is that he who deceives us is not one of us. It is noted that there are no words / expressions belong to the religious genre, although there is an implicit meaning referring to Muslims ( لليس منا ). Here (منا) means (المسلمون). One action verb is used transitively, the other is state. At the sentence level, it is a text of one complex

\begin{tabular}{|c|c|c|c|c|c|c|c|c|c|c|c|c|c|c|}
\hline \multirow{3}{*}{ 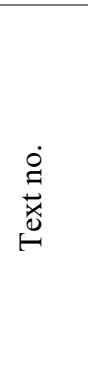 } & \multirow[b]{3}{*}{ 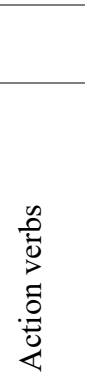 } & \multicolumn{4}{|c|}{ The word level } & \multicolumn{8}{|c|}{ The Sentence level } & \multirow{3}{*}{ 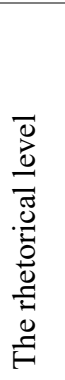 } \\
\hline & & & & & & \multicolumn{3}{|c|}{ Sentence Type } & \multicolumn{3}{|c|}{ Sentence Mode } & \multicolumn{2}{|c|}{ Tenses } & \\
\hline & & 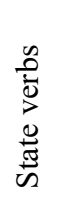 & 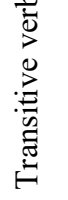 & 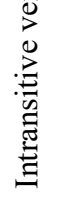 & 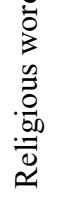 & $\begin{array}{l}\frac{0}{2} \\
\stackrel{\Xi}{\mathscr{a}}\end{array}$ & $\begin{array}{l}\vec{\Xi} \\
\bar{\Xi} \\
\text { ڤ్ğ } \\
0\end{array}$ & 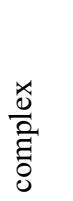 & 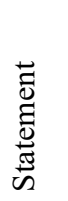 & 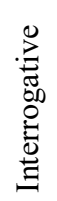 & 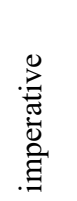 & $\begin{array}{l}\breve{D} \\
\ddot{D} \\
0 \\
0\end{array}$ & $\begin{array}{l}\overrightarrow{\tilde{O}} \\
\tilde{\Xi}\end{array}$ & \\
\hline 1 & 1 & & & 1 & 1 & 1 & & & & & 1 & 1 & & \\
\hline 2 & 3 & 2 & 3 & 2 & 4 & & & 1 & 5 & & & & 5 & 7 \\
\hline 3 & 2 & 2 & & 4 & 4 & & & 1 & 1 & & 3 & 3 & 1 & 4 \\
\hline 4 & 2 & & 1 & 1 & 1 & & 1 & & 2 & & & 2 & & 2 \\
\hline 5 & 2 & & 1 & 1 & 4 & & & 1 & 2 & & & & 2 & \\
\hline 6 & 1 & 1 & 1 & 1 & & & & 1 & 1 & & & & 2 & \\
\hline Total & 11 & 5 & 6 & 10 & 14 & 1 & 1 & 4 & 11 & & 4 & 6 & 10 & 13 \\
\hline$\%$ & 23.9 & 10.9 & 13.0 & 21.7 & 30.4 & 2.8 & 2.8 & 10.8 & 29.7 & & 10.8 & 16.2 & 27.0 & 15.7 \\
\hline
\end{tabular}
sentence whose tense is simple past. The mode is statement. No rhetorical devices are manipulated.

Table 2. The Distribution of Micro Structures in the Arabic Data

The numbers and percentages, in table (2), show that action and intransitive verbs, as far as the word level is concerned, constitute the highest rates of frequency $(23.9 \%)$ and $(21.7 \%)$ respectively. This shows the dynamicity of ideas. At the sentence level, statement type of sentence has the highest rate of frequency $(29.7 \%)$. This indicates that the focus of the Arabic Hadith is on the statement of the facts. It is also found that past tense is used more than present tense (27\%) 
versus (16.2\%). According to many Arabic Rhetoricians and linguists, past tense is the best stylistic tool for expressing emphasis e.g. من غشنا فليس منا and many other examples. The Glorious Quran is full of such examples. Regarding the rhetorical level, it is noticed that a variety of rhetorical devices is manipulated to facilitate grasping the main idea. No use of passive constructions is noted in all the selected texts. This emphasizes the fact that in the Arabic Hadith there is a focus on the direct presentation of the ideas and instructions.

\section{Contrasting English and Arabic texts}

In both English and Arabic data, it has been found that there is a similarity on the word level, in the use of action and transitive verbs. Both languages prefer such types of verbs: (14.2\% and 19\%) for the English action and transitive verbs respectively and $23.9 \%$ and $21.7 \%$ for the Arabic action and transitive verbs respectively. Regarding sentence types and modes, the two languages differ in their manipulation of sentence types, i.e. in the English data, there is a preference towards using compound type of sentences (9.7\%) while in the Arabic data, there is a focus on the use of complex type of sentences (10.8\%). The two languages prefer using statements more than other sentence modes $(9.7 \%$ and $29.7 \%$ respectively). This proves that they have an interest in the statement of facts.

Conversely, the two types of texts are noticeably different in their employment of tense. In the English data, present tense is highly manifested (17.4\%) since one of its uses is to express facts. In the Arabic data, on the other hand, past tense is highly preferred (27\%) as it is one of the main stylistic devices to express emphasis.

Moreover, the two languages are noticeably different in their use of religious words/ expressions. They show a significant variation in their frequency rates: (7.9\%) for the English data and (30.4\%) for the Arabic data. Also, the difference between the two languages extends to include the rhetorical devices, it is clearly noticed that in the Arabic language, since it is the language of the Glorious Quran, there is a tendency to use rhetorical devices $(15.7 \%)$ which are considered as tools serving understanding. While in the English data no such tendency is found (7.9\%).

\section{Conclusion}

The analysis has shown that the macro structures of both English and Arabic texts are the integration of the lexical, Syntactic and rhetorical levels. It has also proved that each type of text has its significant micro structures characterized by lexical, syntactic and rhetorical elements.

It has been found that the English texts are more inclined to use compound type of sentences more than the Arabic counterparts which are interested in complex ones. The former concentrate on using present tense while the latter prefer using past tense for stylistic purposes. No significant use of religious words/ expressions and rhetorical devices is noted as far as the English texts are concerned.

Conversely, in the Arabic texts, there is a high preference to use religious words and a certain set of rhetorical devices.

The area of similarity between the two languages is very limited. Both of them favour the use of action and transitive verbs more than other classes of verbs. As far as the sentence level is concerned, both languages prefer using statements more than other sentence modes.

\section{References}

Al-Bukhari, M. (d 256 AH) (2007). Sahih ul-Bukhari. Translated into English by: Al-Sharif, M. Beirut: Dar Al-Kotob Al-Ilmiyah.

Bellert, I. (1970). Conditions of the Cohernece of a text. Semiotica 2, 335-363

Hamburger, H. (1981). The Function of the Predicate in the Fables of Krylov: A Case Grammatical Study. Amesterdam: Rodopi.

Rayshahri, M. (2009). The Scale of Wisdom A Compendium of Shi'a Hadith. Dar ul-Hadith Punlication. Iran. Van Dijk, T.A. (1972). Some Aspects of Texts Grammar. The Hague: Mounton

(1977). Text and Context. London: Longman.

(1980). Macrostructures: An interdisciplinary Study of Global Structures in Discourse, Interaction and Cognition. New Jersey: Lawrence Erlbaum Associates Inc. (1981). Studies in the Pragmatics of the Discourse. The Netherlands: Mouton.

(1985). Handbook of Discourse Analysis: Discourse Analysis in Society. London: Academic Press.

Van Dick, T.A. and Kintch, W. (1983). Strategies of Discourse Comprehension. NewYork: Academia Press. 